\title{
Plasma renin activity in coarctation of aorta before and after surgery
}

\author{
A. Markiewicz, D. Wojczuk, F. Kokot, and A. Cicha \\ From the and Medical Clinic, Institute of Internal Diseases, Silesian School of Medicine, Katowice; and \\ Department of Pediatric Cardiology, Municipal Hospital No. 2, Katowice, Poland
}

Plasma renin activity was measured in II cases of coarctation of the aorta before and after operation. The values of plasma renin activity in the recumbent position before operation were significantly lower than in the control group. After surgery plasma renin activity rose to normal levels. There was no correlation between plasma renin activity levels and arterial blood pressure. The renin-angiotensin system seems not to be involved directly in the maintenance of hypertension in patients with aortic coarctation.

The pathogenesis of the arterial hypertension in the upper part of the body in cases of coarctation of the aorta is not clear. Patients with coarctation are necessarily studied when compensatory changes in the circulation have already occurred, as shown by the similar values of renal blood flow in these patients when compared with normal subjects (Werko et al., 1956; Culbertson et al., 1957; Kirkendall, Culbertson, and Eckstein, 1959; Timmis and Gordon, 1964; Kroetz, Kirkendall, and Kioschos, 1968). In attempts to study the mechanism(s) initiating hypertension, most workers have relied on observations made during the first hours or days after experimental constriction of the aorta. More recently, long-term experiments have been reported (Yagi et al., 1968; Ledingham, 1971) on a model more similar to the conditions encountered in man. The latter studies suggest that the chronic phase of hypertension with coarctation of the aorta is not associated with an increase in peripheral plasma renin activity.

Observations in patients with coarctation before and after surgical restoration of normal haemodynamics have been performed only rarely. Such studies are important because after successful operation the mean arterial blood pressure as well as the pulsatility of blood flow is increased in the area distal to the narrowed aorta.

The aim of this study was to measure the plasma renin activity in patients with coarctation of the aorta before and after successful surgical treatment in order to assess the possible role of the reninangiotensin system in the production of the hypertension in these patients.

Received 6 January 1975.

\section{Subjects and methods}

The study group consisted of II patients aged 5 to 20 years (mean 10.3 years). The diagnosis of coarctation of the aorta was established on the basis of the usual clinical criteria and confirmed at operation in each case. In 4 patients there was also a persistent ductus arteriosus (Cases 4, 7, 9, and II), while another (Case 5) had clinical evidence of aortic regurgitation. All the examinations were done first before the operation, repeated 2 to 4 weeks after operation, and again 3 to 6 months after operation. No drugs were given during this period.

Plasma renin activity was assayed in blood taken from an antecubital vein after at least 5 hours in the recumbent position in patients taking a diet containing 80 to IIO mmol sodium daily ('recumbent plasma renin activity'). During the next 24 hours the patients received a sodium-restricted diet (less than $10 \mathrm{mmol} \mathrm{Na}$ /day) and 40 to $80 \mathrm{mg}$ frusemide in two divided doses orally. The next day blood samples were taken again, after the patient had maintained the upright position, walking or standing, for 2 hours ('upright plasma renin activity'). Plasma renin activity was assayed by the method described by Boucher et al. (1964) and was expressed in terms of nanograms of angiotensin II released under the influence of the enzyme per $100 \mathrm{ml}$ of plasma during incubation for 3 hours at $37^{\circ} \mathrm{C}$.

Immediately after sampling the blood for 'recumbent plasma renin activity', arterial blood pressure was measured in the upper and lower extremities on the left side (auscultatory method of Korotkoff). Within the next 24 hours, sphygmo-oscillometry was performed in each case on the same extremity (using an Infraton OS 3 sphygmo-oscillograph, Boucke-Brecht type, with synchronized automatic recording of blood pressure in mmHg). Two curves were recorded; the first was taken during uniformly falling pressure in the cuff (from 300 to $\circ \mathrm{mmHg}$ (40 to $\circ \mathrm{kPa})$ ) and the mean blood pressure 
TABLE I Vascular and renal function tests

\begin{tabular}{|c|c|c|c|c|c|c|c|}
\hline & \multirow{2}{*}{$\begin{array}{l}\text { No. of } \\
\text { patients }\end{array}$} & \multicolumn{2}{|c|}{ Before operation } & \multicolumn{2}{|c|}{ After operation } & \multirow[t]{2}{*}{$t$} & \multirow[t]{2}{*}{$P$} \\
\hline & & Mean & Range & Mean & Range & & \\
\hline \multirow{3}{*}{$\begin{array}{l}\text { Time of ascending pulse wave (s) } \\
\begin{array}{lc}\text { Pulsatile volume } & \text { Left upper } \\
\left(\mathrm{mm}^{3}\right) & \text { extremity } \\
& \text { Left lower } \\
& \text { extremity }\end{array}\end{array}$} & II & 0.25 & $0.20-0.36$ & 0.18 & $0.14-0.30$ & 5.22 & $<0.001$ \\
\hline & II & 207 & $68-662$ & 121 & $50-346$ & 3.17 & $<0.01$ \\
\hline & II & II6 & $16-210$ & $24 I$ & $138-312$ & -7.21 & $<0.001$ \\
\hline \multirow{2}{*}{$\begin{array}{c}\text { Clearance PAH (ml/min per } \\
\left.1.73 \mathrm{~m}^{2}\right) \\
\text { Renal blood flow (ml/min per } \\
\left.1.73 \mathrm{~m}^{2}\right)\end{array}$} & $10^{\star}$ & 395 & $248-587$ & 391 & I42-699 & 0.08 & NS \\
\hline & $10^{\star}$ & 635 & $386-1029$ & 651 & $233-1092$ & -0.19 & NS \\
\hline \multirow{2}{*}{$\begin{array}{cc}\begin{array}{c}\text { Radioisotope } \\
\text { renography (s) }\end{array} & \begin{array}{c}\text { Vascular and } \\
\text { tubular phase } \\
\text { Excretory } \\
\text { phase }\end{array}\end{array}$} & $8 t$ & 297 & $150-480$ & 278 & $180-367$ & 0.44 & NS \\
\hline & $8 t$ & 426 & $240-615$ & 348 & $135-488$ & 1.50 & NS \\
\hline
\end{tabular}

* Excluding Case 11 .

† Excluding Cases 2, 9, and 10.

was determined from the highest pulse amplitude; the second tracing was recorded at constant pressure equal to the mean arterial pressure. The time of the ascending pulse wave in the lower extremity (in seconds) and pulsatile blood volume of the extremity (in $\mathrm{mm}^{3}$ ) were calculated from this curve as compared with the standard pattern (Singer and Kudybyn, 1969).
Serum creatinine concentration, para-aminohippuric acid clearance (Kokot, 1969) and ${ }^{131}$ I-labelled sodium hippurate renography was performed in 8 patients (Table I). Renal blood flow was calculated from the estimated renal plasma flow and the haematocrit.

Plasma renin activity was also determined in Io normal children aged 6 to 14 years (mean 10.3 years) under

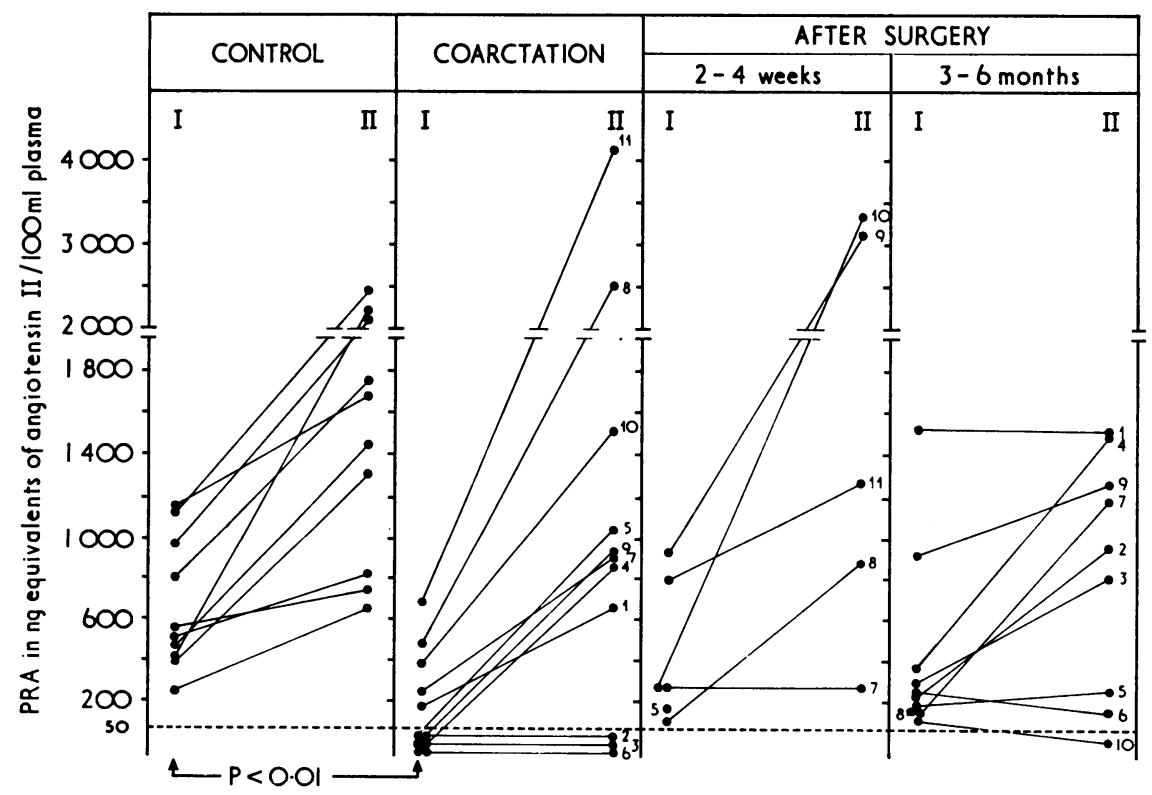

FIG. Plasma renin activity in recumbent (I) and upright (II) positions. 
TABLE 2 Blood pressure and plasma renin activity

\begin{tabular}{|c|c|c|c|c|c|c|c|c|}
\hline \multirow[t]{2}{*}{$\begin{array}{l}\text { Case } \\
\text { No. }\end{array}$} & \multirow[t]{2}{*}{$\begin{array}{l}\text { Age }(y r) \\
\text { sex }\end{array}$} & \multirow[t]{2}{*}{ Sampling } & \multicolumn{2}{|c|}{ Blood pressure $(\mathrm{mmHg})^{\star}$} & \multicolumn{2}{|c|}{$\begin{array}{l}\text { Mean blood pressure } \\
\quad(\mathrm{mmHg})\end{array}$} & \multicolumn{2}{|c|}{$\begin{array}{l}\text { Plasma renin activity } \\
\quad(\mathrm{ng} / \mathrm{I} 00 \mathrm{ml})\end{array}$} \\
\hline & & & Arm & Leg & Arm & Leg & $\begin{array}{l}\text { Recum- } \\
\text { bent }\end{array}$ & Upright \\
\hline \multirow[t]{2}{*}{$\mathbf{I}$} & $6, M$ & Before & $120 / 70$ & $t$ & 100 & 90 & I 80 & 660 \\
\hline & & After $4 \mathrm{mth}$ & $105 / 60$ & II $5 / 80$ & 90 & 90 & I 575 & 1500 \\
\hline \multirow[t]{2}{*}{2} & $6, F$ & Before & $160 / 90$ & $t$ & IIO & 85 & $<50$ & $<50$ \\
\hline & & After $5 \mathrm{mth}$ & $120 / 70$ & I $10 / 70$ & 105 & 105 & 220 & 945 \\
\hline \multirow{2}{*}{3} & $7, M$ & Before & $155 / 60$ & $t$ & 100 & 70 & $<50$ & $<50$ \\
\hline & & After $4 \mathrm{mth}$ & I I5/70 & II $5 / 80$ & 90 & 90 & 300 & 807 \\
\hline \multirow[t]{2}{*}{4} & I4, M & Before & $140 / 80$ & $t$ & I 10 & 90 & $<50$ & 887 \\
\hline & & After $3 \mathrm{mth}$ & $120 / 70$ & $135 / 70$ & 100 & 115 & 375 & I590 \\
\hline \multirow[t]{2}{*}{5} & II, $M$ & Before & I40/95 & $t$ & 130 & 100 & $<50$ & 1027 \\
\hline & & After 4 wk & ND & ND & ND & ND & 150 & ND \\
\hline \multirow{2}{*}{6} & $20, \mathrm{M}$ & $\begin{array}{l}\text { After } 6 \mathrm{mth} \\
\text { Before }\end{array}$ & $\begin{array}{l}120 / 80 \\
220 / 80\end{array}$ & $\begin{array}{l}125 / 80 \\
t\end{array}$ & $\begin{array}{l}100 \\
130\end{array}$ & $\begin{array}{r}110 \\
00\end{array}$ & $\begin{array}{r}195 \\
<50\end{array}$ & $\begin{array}{r}247 \\
<50\end{array}$ \\
\hline & & After $3 \mathrm{mth}$ & $170 / 70$ & $120 / 70$ & I10 & $\begin{array}{r}90 \\
100\end{array}$ & 225 & 140 \\
\hline \multirow[t]{3}{*}{7} & $9, M$ & Before & $130 / 70$ & $t$ & 100 & 85 & 262 & 900 \\
\hline & & After I7 dy & $95 / 65$ & $90 / 60$ & 100 & 95 & 270 & 270 \\
\hline & & After $5 \frac{1}{2} \mathrm{mth}$ & $95 / 65$ & $100 / 60$ & 90 & 100 & 123 & II63 \\
\hline \multirow[t]{3}{*}{8} & II, F & Before & $175 / 80$ & $t$ & IIO & 85 & 495 & 2494 \\
\hline & & After 3 wk & $160 / 75$ & Trace & 90 & II 5 & I10 & 850 \\
\hline & & After $5 \frac{1}{2} \mathrm{mth}$ & $180 / 80$ & Trace & 100 & 100 & 187 & ND \\
\hline \multirow[t]{3}{*}{9} & $8, F$ & Before & $130 / 70$ & $t$ & 120 & 90 & $<50$ & 900 \\
\hline & & After 4 wk & $115 / 70$ & $120 / 80$ & 90 & 95 & 922 & 3000 \\
\hline & & After $6 \mathrm{mth}$ & I I $5 / 60$ & II $5 / 70$ & 95 & 100 & 915 & 1245 \\
\hline \multirow[t]{3}{*}{ 10 } & I6, M & Before & $160 / 80$ & $t$ & 140 & 100 & 397 & I 575 \\
\hline & & After 2 wk & $160 / 80$ & Trace & 100 & II5 & 270 & 3300 \\
\hline & & After $6 \mathrm{mth}$ & $150 / 85$ & Trace & IIs & 105 & 123 & $<50$ \\
\hline \multirow[t]{2}{*}{ II } & $5, M$ & Before & $130 / 80$ & $t$ & IIO & 75 & 690 & 4200 \\
\hline & & After 2 wk & $110 / 80$ & $90 / 60$ & 100 & 90 & 794 & 1250 \\
\hline
\end{tabular}

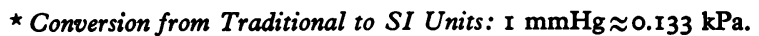

+ No value obtainable.

ND $=$ not determined.

the same dietary circumstances. The results were analysed by the paired ' $t$ ' test (Table $I$ ) and group ' $t$ ' test (Fig.).

\section{Results}

After operation femoral pulses were palpable in each case. The time delay of the ascending pulse wave in the legs shortened significantly in all cases after operation (Table I). The pulsatile volume also changed significantly becoming less in the upper extremity, and increasing in the lower limb.

As shown in Table $I$, renal haemodynamics did not change after operation; the serum creatinine level also remained unaltered (less than $106 \mu \mathrm{mol} / 1$ ( $1.2 \mathrm{mg} / 100 \mathrm{ml}$ ) in each case).

Arterial blood pressure in the upper extremities decreased after operation in 9 of the II patients (Table 2), while the blood pressure in the lower limbs usually increased (average change $15 \mathrm{mmHg}$ $(2 \mathrm{kPa})$ ). In two patients (Cases 8 and $\mathrm{ro}$ ), arterial blood pressure in the lower extremities was still unmeasurable, though the femoral pulses became weakly palpable and the mean blood pressure as well as pulsatile volume increased.

The plasma renin activity in the control group of ro children while recumbent was $667 \pm 315 \mathrm{ng} / 100$ $\mathrm{ml}$ of angiotensin II rising to $\mathrm{I} 493 \pm 6 \mathrm{II} \mathrm{ng} / 100 \mathrm{ml}$ in the upright position (Fig). These values are higher than those for healthy adults determined in our laboratory: $219 \pm 24 \mathrm{ng} / 100 \mathrm{ml}$ recumbent and $1082 \pm 100 \mathrm{ng} / 100 \mathrm{ml}$ in the upright position (Kokot and Kuska, 1972).

Table 2 and the Fig show the plasma renin activity estimations. In 6 patients while recumbent before operation, only trace values of plasma renin activity were found: in 2 others the levels were subnormal and plasma renin activity was normal in the remaining 3 cases. Recumbent plasma renin activity in cases of coarctation of the aorta was significantly lower than in the control group $(\mathbf{P}<0.01)$. After operation, plasma renin activity increased in 8 patients and the mean value was no 
TABLE 3 Plasma renin activity before $(A)$ and after surgery $(B)$, as determined by various authors

\begin{tabular}{|c|c|c|c|c|c|c|c|c|c|}
\hline \multirow[t]{2}{*}{ Author } & \multirow[t]{2}{*}{ Position } & \multirow{2}{*}{$\begin{array}{l}\text { No. of } \\
\text { patients }\end{array}$} & \multicolumn{3}{|l|}{$A$} & \multirow{2}{*}{$\begin{array}{l}\text { No. of } \\
\text { patients }\end{array}$} & \multicolumn{3}{|l|}{$B$} \\
\hline & & & Low & Normal & High & & Decrease & No change & Increase \\
\hline \multirow{5}{*}{$\begin{array}{l}\text { Brown et al. (1965) } \\
\text { Genest et al. (1965) } \\
\text { Pickens (1967) } \\
\text { Imbs, Desaulles, and } \\
\text { Bloch (1968) }\end{array}$} & Recumbent & 4 & & 4 & & I & & & $\mathbf{r}$ \\
\hline & Recumbent & 4 & & 2 & 2 & & & & \\
\hline & Recumbent & I & & & $\mathbf{I}$ & $\mathbf{I}$ & $\mathbf{I}$ & & \\
\hline & Recumbent & 6 & $\mathbf{I}$ & 2 & 3 & & & & \\
\hline & Upright & 4 & $\mathbf{I}$ & 2 & $\mathbf{I}$ & & & & \\
\hline \multirow{4}{*}{$\begin{array}{l}\text { Kroetz et al. (1968) } \\
\text { Amsterdam et al. } \\
\text { (I969) } \\
\text { Werning et al. (1969) }\end{array}$} & Recumbent & 5 & & 5 & & & & & \\
\hline & Recumbent & 16 & $15 t$ & & I & & & & \\
\hline & Recumbent & Io & & 9 & $\mathbf{I}$ & & & & \\
\hline & Upright & I0 & & 9 & $\mathbf{I}$ & & & & \\
\hline \multirow[t]{2}{*}{ Strong et al. (1970) } & Recumbent & 12 & $\mathbf{I}$ & 7 & 4 & $12 \ddagger$ & 6 & 4 & 2 \\
\hline & Upright & 3 & & 3 & & & & & \\
\hline \multirow[t]{2}{*}{ Present paper } & Recumbent & II & 6 & 5 & & II & 2 & & 9 \\
\hline & Upright & II & 3 & 6 & 2 & II & 4 & 2 & 5 \\
\hline \multirow[t]{2}{*}{ Totals } & Recumbent & 69 & 23 & 34 & 12 & 25 & 9 & 4 & 12 \\
\hline & Upright & 28 & 4 & 20 & 4 & II & 4 & 2 & 5 \\
\hline
\end{tabular}

† All values below the mean control value.

¥ Only long-term (mean 112 days) postoperative data.

longer significantly different from the control group.

Before surgery 'upright' plasma renin activity was subnormal in 3 patients, abnormally high in 2 patients, and within the normal range in the remainder. The influence of surgical repair on upright plasma renin activity was variable (Fig.).

\section{Discussion}

Surgery was successful in returning palpable femoral pulses in all the patients; blood pressures could be measured in the lower extremities after operation in all but 2 patients and the mean blood pressure rose significantly in Io of the II cases.

The significant increase in pulsatile volume and the conspicuous shortening of the ascending arm of the pulse wave in the lower extremities after operation are taken as indirect evidence of increasing pulsatility of blood flow in the whole area below the previously narrowed aorta. Renal blood flow, measured before and after operation, was normal. Thus, the renal haemodynamics in the patients appeared independent either of the aortic lesion or of changing systemic circulation.

From the observations on plasma renin activity it appears that hypertension in aortic coarctation is not associated with raised values. Indeed in half the patients only trace levels of plasma renin activity were noted with the patients recumbent. The increase in plasma renin activity provoked by sodium depletion and the upright posture raised the levels to the normal range in 8 cases while no change was detected in the remainder.
After operation, recumbent plasma renin activity increased in the majority of patients, including those with trace levels before operation. No correlation was found between plasma renin activity and arterial blood pressure.

Previous measurements of the renin-angiotensin system in patients with coarctation yielded variable results. Some authors determined angiotensin II levels in the blood; Morris, Robinson, and Scheele (1964) found raised levels in all 9 patients, but their results were methodologically questionable (Werning et al., 1969). Massani et al. (1966) in 2 patients and Ueda, Kaneko, and Takeda (1966) noted normal blood values of angiotensin II. Sealy (1967) examined 5 patients and found normal angiotensin levels in 3 while high values were reported in the other 2 cases, both of whom had complications. Timmis and Gordon (1964) examined 3 patients and found no significant changes in excretion of aldosterone in 24-hour urine either before or after operation.

Plasma renin values have been studied more frequently in this syndrome. The results obtained by various authors are given in Table 3. It can be seen that of a total of 69 cases the levels were normal in $34(50 \%)$, while in the other cases the levels were either higher (12) or lower (23) than the normal range. Similar results were obtained with plasma renin activity in upright position; 85.7 per cent of cases had low or normal values. The evaluation of the role and the significance of the renin-angiotensin system in coarctation of the aorta is difficult, since 
the mechanisms controlling the autoregulation of renal blood flow and of renin release are still not clear.

In a recently published review on the physiological significance of renin, Stein and Ferris (1973) mention Io factors with a possible influence on the secretion of this enzyme. Two of them seem more important: arterial blood pressure (baroreceptor theory formulated by Tobian (1967)) and the sodium macula densa theory, according to Vander and Miller (1964).

As far as we are aware the only other report including both pre- and postoperative measurements of renin in coarctation is that of Strong et al. (1970). They did not find a rise in recumbent plasma renin activity after operation, as was observed in our series.

In view of these collected results, it seems evident that coarctation of the aorta in subjects older than 5 years is not usually associated with a decrease in renal blood flow nor in renal function. Neither does it provoke a persistent increase in plasma renin levels; on the contrary circulating renin is normal or low. After surgical repair of the aortic lesion plasma renin activity seems to enter the normal range. Thus, the mechanisms of prolonged systemic hypertension in aortic coarctation seem not to be related directly to overactivity of the renin-angiotensin system.

The authors would like to thank Dr. J. J. Brown (MRC Blood Pressure Research Unit, Western Infirmary, Glasgow), for his advice and help in the improvement of the manuscript. We also are indebted to Professor HagerMatecka, for her permission to include, as a control group, the patients of the rst Children's Clinic of the Silesian School of Medicine.

\section{References}

Amsterdam, E. A., Albers, W. H., Christlieb, A. R., Morgan, C. L., Nadas, A. S., and Hickler, R. B. (1969). Plasma renin activity in children with coarctation of the aorta. American fournal of Cardiology, 23, 396.

Boucher, R., Veyrat, R., de Champlain, J., and Genest, J. (1964). New procedures for measurement of human plasma angiotensin and renin activity levels. Canadian Medical Association fournal, 90, 194.

Brown, J. J., Davies, D. L., Lever, A. F., and Robertson, J. I. S. (1965). Plasma renin concentration in human hypertension. II: Renin in relation to aetiology. British Medical fournal, 2, 1215.

Culbertson, J. W., Eckstein, J. W., Kirkendall, W. M., and Bedell, G. N. (1957). General hemodynamics and splanchnic circulation in patients with coarctation of the aorta. Fournal of Clinical Investigation, 36, 1537.

Genest, J., de Champlain, J., Strong, C., and Boncher, R. (1965). Le système rénine - angiotensine dans l'hypertension humaine C.I.H.T.A. In Symposium on Hypertension, 1965, I vol, p. 130. Ed. by P. Milliez. Expansion éd., Paris.
Imbs, J. L., Desaulles, E., and Bloch, R. B. (I968). Coarctation de l'aorte et ischémie rénale. Semaine des Hópitaux de Paris, 44, 1653.

Kirkendall, W. M., Culbertson, J. W., and Eckstein, J. W. (1959). Renal hemodynamics in patients with coarctation of the aorta. Fournal of Laboratory and Clinical Medicine, 53,6 .

Kokot, F. (1969). Metody badań laboratoryjnych stosowanych w klinice. (Clinical Laboratory Methods.) PZWL, Warszawa.

Kokot, F., and Kuska, J. (1972). About some aspects of plasma renin activity estimations in hypertensive patients. Cor et Vasa, 14, 22.

Kroetz, F. W., Kirkendall, W. M., and Kioschos, M. (1968). Renal blood flow (RBF) and renin release rates (RRR) in coarctation of the aorta (abstract). Circulation, 38, Suppl. VI, 120.

Ledingham, J. M. (1971). Mechanisms in renal hypertension. Proceedings of the Royal Society of Medicine, 64, 409.

Massani, Z. M., Finkielman, S., Worcel, M., Agrest, A., and Paladini, A. C. (1966). Angiotensin blood levels in hypertensive and non-hypertensive diseases. Clinical Science, 30, 473.

Morris, R. E., Jr., Robinson, P. R., and Scheele, G. A. (1964). The relationship of angiotensin to renal hypertension. Canadian Medical Association fournal, 90, 272.

Pickens, P. T. (1967). Relation of plasma renin to blood pressure in a patient with coarctation. British Heart fournal, 29, 135 .

Sealy, W. C. (1967). Coarctation of the aorta and hypertension. Annals of Thoracic Surgery, 3, 15 .

Singer, K., and Kudybyn, R. (1969). Wartosc diagnostyczna badania tetnic metoda sfigmooscylograficzna. (Diagnostic value of examination of the arteries by the method of sphygmo-oscillography.) Polski Tygodnik Lekarski, 24, I37r.

Stein, J. H., and Ferris, T. F. (1973). The physiology of renin. Archives of Internal Medicine, 131, 860.

Strong, W. B., Botti, R. E., Silbert, D. R., and Liebman, J. (1970). Peripheral and renal vein plasma renin activity in coarctation of the aorta. Pediatrics, 45, 254.

Timmis, G. C., and Gordon, S. (1964). A renal factor in hypertension due to coarctation of the aorta. New England Fournal of Medicine, 270, 814.

Tobian, L. (1967). Renin release and its role in renal function and the control of salt balance and arterial pressure. Federation Proceedings, 26, 48.

Ueda, H., Kaneko, Y., and Takeda, T. (1966). Renal pressor system in hypertensive patients. Fapanese Circulation fournal, 30, 167 .

Vander, A. J., and Miller, R. (1964). Control of renin secretion in the anesthetized dog. American fournal of Physiology, $207,537$.

Werko, L., Ek, J., Bucht, H., and Karnell, J. (1956). Cardiac output, blood pressures and renal dynamics in coarctation of the aorta. Scandinavian fournal of Clinical and Laboratory Investigation, 8, 193.

Werning, C., Schönbeck, M., Weidmann, P., Baumann, K., Gysling, E., Wirz, P., and Siegenthaler, W. (1969). Plasma renin activity in patients with coarctation of the aorta: a comment on the pathogenesis of prestenotic hypertension. Circulation, 40, 731.

Yagi, S., Kramsch, D. M., Madoff, I. M., and Hollander, W. (1968). Plasma renin activity in hypertension associated with coarctation of the aorta. American fournal of Physiology, 215, 605.

Requests for reprints to Dr. A. Markiewicz, 2nd Medical Clinic, ul Francuska 20, 40-027 Katowice, Poland. 